\title{
Unequal Anthropogenic Enrichment of Mercury in Earth's Northernand Southern Hemispheres
}

\author{
CHUXIAN LI ${ }^{1,2}$, JEROEN E SONKE $^{3}$, GAEL LE ROUX ${ }^{4}$, \\ NATALIA PIOTROWSKA ${ }^{5}$, NATHALIE VAN DER \\ PUTTEN $^{6}$, STEPHEN J. ROBERTS ${ }^{7}$, TIM DALEY $^{8}$, EMMA \\ RICE $^{8}$, ROLAND GEHRELS ${ }^{9}$, MAXIME ENRICO ${ }^{10}$, DMITRI \\ MAUQUOY ${ }^{11}$, THOMAS P. ROLAND ${ }^{12}$ AND FRANÇOIS \\ DE VLEESCHOUWER ${ }^{13}$ \\ ${ }^{1}$ Department of Forest Ecology \& Management, Swedish \\ University of Agricultural Sciences \\ ${ }^{2}$ EcoLab, Université de Toulouse, CNRS, INPT, UPS \\ ${ }^{3} \mathrm{CNRS} /$ Université de Toulouse \\ ${ }^{4}$ EcoLab-CNRS Toulouse \\ ${ }^{5}$ Silesian University of Technology \\ ${ }^{6}$ Vrije Universiteit Amsterdam \\ ${ }^{7}$ British Antarctic Survey \\ ${ }^{8}$ Plymouth University \\ ${ }^{9}$ University of York \\ ${ }^{10}$ Harvard University \\ ${ }^{11}$ University of Aberdeen \\ ${ }^{12}$ Geography, College of Life and Environmental Sciences, \\ University of Exeter \\ ${ }^{13}$ Instituto Franco-Argentino para el Estudio delClima y \\ sus Impactos (UMI 3351 IFAECI/CNRS-CONICET- UBA), \\ Universidad de Buenos Aires \\ Presenting Author: chuxian.li@slu.se
}

Remote Northern Hemisphere (NH) and Southern Hemisphere (SH) lake sediment and peat records of mercury $(\mathrm{Hg})$ deposition have shown a $\times 3$ to $\times 5 \mathrm{Hg}$ enrichment since pre-industrial times ( $<1880$ AD), leading to the perception that global atmospheric $\mathrm{Hg}$ enrichment is moderate and uniform across the hemispheres. Anthropogenic $\mathrm{Hg}$ emissions in the $\mathrm{NH}$ are, however, approximately 4 times higher than those in the SH. Here, we reconstruct atmospheric $\mathrm{Hg}$ deposition in four remote $\mathrm{SH}$ peatlands and review sediment and peat $\mathrm{Hg}$ records from both hemispheres. We observe a $\times 4$ all-time enrichment in $\mathrm{SH} \mathrm{Hg}$ deposition from pre-anthropogenic $(<1450 \mathrm{AD})$ to the late 20thcentury periods, which is lower than the large $\times 16$ all-time enrichment in $\mathrm{NH} \mathrm{Hg}$ deposition. We attribute this difference to lower anthropogenic $\mathrm{Hg}$ emissions in the $\mathrm{SH}$, and higher natural atmospheric $\mathrm{SH} \mathrm{Hg}$ concentrations, supported by $\times 2$ higher natural background $\mathrm{Hg}$ accumulation in $\mathrm{SH}$ peat records. We suggest that the higher $\mathrm{SH}$ natural atmospheric $\mathrm{Hg}$ deposition reflects the SH land-ocean distribution, and is driven by important $\mathrm{SH}$ marine $\mathrm{Hg}$ emissions. Our findings indicate that atmospheric $\mathrm{Hg}$ background levels and anthropogenic enrichment in both hemispheres are different and should be taken into account in international $\mathrm{Hg}$ assessments and environmental policy. 